\title{
Prevalence and Interpretation of Recent Trends in Rates of Pervasive Developmental Disorders
}

\author{
Eric Fombonne*, Sara Quirke, Arlene Hagen
}

\begin{abstract}
The aims of this article are to provide an up-to-date review of the methodological features and substantive results of published epidemiological surveys of the prevalence of pervasive developmental disorders (PDD). This article updates previous reviews $(1,2)$ with the inclusion of new studies made available since then. The specific questions addressed inthis article are: a) how are cases of PDD defined and identified in epidemiological surveys?; b) what are the best estimates for the prevalence of autism and related pervasive developmental disorders considering the methodological implications of the surveys, and c) what interpretation can be given to time trends observed in prevalence rates of PDDs given the hypothesized secular increase in PDDs?
\end{abstract}

\section{INTRODUCTION}

\section{Selection of Studies}

The studies were identified through systematic searches from the major scientific literature databases and from prior reviews (1-3). Only studies published in the English language were included. Overall, 57 studies published between 1966 and 2009 were selected which surveyed PDDs in 17 countries; half of the studies have been published since 2001. The age range of the population included in the surveys is spread from birth to early adult life, but most studies have relied on school-aged samples. There was huge variation in the size of the population surveyed (mean: 279,000; median: 44,900).

\section{Study Designs}

In designing a prevalence study, two major features are critical for the planning and logistics of the study, as well as for the interpretation of its results: case definition, and case ascertainment (or case identification methods) (4).

\footnotetext{
*To whom correspondence should be addressed:

Eric Fombonne,

Canada Research Chair in Child Psychiatry

McGill University

Department of Psychiatry

The Montreal Children's Hospital

4018 St. Catherine St. W.

Montreal, QC H3Z 1P2

Canada

E-mail: eric.fombonne@mcgill.ca
}

\section{Case Definition}

Over time, the definitions of autism have changed as illustrated by the numerous diagnostic criteria that were used in both epidemiological and clinical settings. The first diagnostic criteria reflected the more qualitatively severe forms of autism and it is only in the 1980s that less severe forms of autism were recognized, either as a qualifier for autism occurring without mental retardation or as separate diagnostic categories within a broader class of autism spectrum disorders (ASD) denominated 'Pervasive developmental disorders' (PDD, an equivalent to ASD) in current nosographies. Current nosographies include the Diagnostic and Statistical Manual of Mental Disorders, Fourth edition, Text Revision (DSMIV- TR) (5) and the International Classification of Diseases, Tenth edition (ICD-10) (6). Whilst there is generally high agreement among experts on the diagnosis of PDD's, some differences persist between nomenclatures about the terminology and precise criteria of PDD's. In addition, in recent years, the definitions of syndromes falling on the autism spectrum have been expanded further with reference to the broader autism phenotype, which is a pattern of mild autistic developmental symptoms seen in relatives of individuals affected with a diagnosed PDD. As no diagnostic criteria are available for these mild forms of autism, the resulting boundaries with the spectrum of PDDs are left uncertain. Whether or not this plays a role in more recent epidemiological studies is difficult to know, but it is a possibility that should be considered in assessing results for the new generation of surveys.

\section{Case Identification}

When an area or population have been identified for a survey, 
some studies have solely relied on existing service providers databases (7); on special educational databases $(8,9,10)$; or, on national registers (11) for case identification. These studies have the common limitations due to relying on local access to existing services for case ascertainment. As a result, subjects with the disorder who are not in contact with these services are not included as cases, leading to an underestimation of the prevalence proportion.

Other investigations have relied on a multi-stage approach to identify cases. The aim of the first screening stage of these studies is to cast a wide net in order to identify subjects possibly affected with a PDD, with the final diagnostic status being determined at a next phase. Then, subjects identified as positive screens go through a more in-depth evaluation to confirm their case status. The source of information used to determine whether an individual has a PDD usually involved a combination of data coming from different sources (medical records, educational sources, other health professionals, etc..), with a direct assessment of the person with autism being offered in some but not all studies. Obviously, surveys of very large populations did not include a direct diagnostic assessment of subjects, as in the studies conducted in the US by the Center for Disease Control (CDC) $(12,13)$ or in national registers (11). However, investigators could generally confirm the accuracy of the diagnosis of their cases by undertaking, on randomly selected subsamples, a more complete diagnostic workup.

When subjects were directly examined, assessments were conducted with various diagnostic instruments, ranging from a typical unstructured examination by a clinical expert (without demonstrated psychometric properties), to the use of batteries of standardized measures by trained research staff. The Autism Diagnostic Interview (14) and/or the Autism Diagnostic Observational Schedule (15) have been increasingly used in the most recent surveys.

\section{PREVALENCE ESTIMATIONS}

\section{Autistic Disorder}

Prevalence estimates for autistic disorder are summarized in Table 1 . There were 47 studies, half of them published since 1999, and the sample size varied from 826 to 4.95 millions, with a median of 38,000 (mean: 217,000) subjects in the surveyed populations. The age ranged from 3 to 15 years, with a median age of 8.5 years. The male/female ratio ranged from 1.33 to 16.0 in 39 studies, leading to an average male/female ratio of 4.3:1. Prevalence rates varied from $0.7 / 10,000$ to $72.6 / 10,000$ with a median value of $12.7 / 10,000$. Small-scale studies reported higher prevalence rates. A significant positive correlation between prevalence rate and year of publication was found. Therefore, a current estimate for the prevalence of autistic disorder must be derived from more recent surveys with an adequate sample size. After exclusion of 4 studies with the smallest and largest sample sizes, the best current estimate for autistic disorder is $22 / 10,000$. In 25 studies where the proportion of subjects with IQ within the normal range was reported, the median value was $20 \%$ (interquartile range: $17.5 \%-50 \%$ ). In these surveys, there was a significant correlation between a higher proportion of normal IQ subjects and a higher male/female ratio (Spearman's r: $0.53 ; p=007$ ), a result consistent with the association between gender and IQ in autism. Over time, there were minor associations between the year of publication of the survey and the sample male/female ratio (Spearman's r: 0.33; $\mathrm{p}=.039)$ and the proportion of subjects without mental retardation (Spearman's r: 0.34; $\mathrm{p}=.094)$. Taken in conjunction with the much stronger increase over time in prevalence rates, these results suggest that the increase in prevalence rates is not entirely accounted for by the inclusion of milder forms (i.e. less cognitively impaired) of autistic disorder, albeit this might have contributed to it to some degree.

\section{Asperger Syndrome}

Epidemiological studies of Asperger Syndrome (AS) are sparse, due to the fact that it was acknowledged as a separate diagnostic category only recently. Twelve studies (already listed in Table 1) published since 1998, have examined samples with respect to the presence of both autistic disorder and Asperger Syndrome. The median population size was 200,000 and the median age 8.25 years. The number of children with AS varied from 6 to 427, with a median sample size of 38. There was a 160 -fold variation in estimated rates of AS (range: 0.3 to $48.4 / 10,000$ ) that highlights the lack of reliability of these estimates. The median value was 11.0/10,000. The prevalence ratio (autistic disorder/ Asperger Syndrome) had a median value of 2.05 , indicating that the rate of AS was consistently lower than that for autism. The epidemiological data on AS are of dubious quality, reflecting difficult nosological issues as well as lack of proper measurement strategies that ensure a reliable difference between AS and autistic disorder.

\section{Childhood Disintegrative Disorder}

Eleven surveys have provided data on childhood disintegrative disorder (CDD). In 5 of these, only 1 case was reported. Prevalence estimates ranged from 0 to $9.2 / 100,000$, with a median rate of $2.0 / 100,000$. The pooled estimate based on 11 identified cases and a surveyed population of about 604,000 children, was $1.8 / 100,000$. 


\begin{tabular}{|c|c|c|c|c|c|c|c|}
\hline$\frac{\text { Year of }}{\text { publication }}$ & Authors & Country & $\begin{array}{l}\text { Size of target } \\
\text { population }\end{array}$ & Age & Diagnostic criteria & $\begin{array}{l}\text { Prevalence } \\
\text { Rate/10,000 } \\
\end{array}$ & $95 \% \mathrm{Cl}$ \\
\hline $\begin{array}{l}1966 \\
1970 \\
1970 \\
1976\end{array}$ & $\begin{array}{l}\text { Lotter (41) } \\
\text { Brask (42) } \\
\text { Treffert (43) } \\
\text { Wing et al. (18) }\end{array}$ & $\begin{array}{l}\text { UK } \\
\text { Denmark } \\
\text { USA } \\
\text { UK } \\
\text { Japan }\end{array}$ & $\begin{array}{c}78.000 \\
46.500 \\
899.750 \\
25,000\end{array}$ & $\begin{array}{l}\text { 10-Aua } \\
\text { 14-Feb } \\
\text { 12-Mar } \\
\text { 14-May }\end{array}$ & $\begin{array}{l}\text { Rating scale } \\
\text { Clinical } \\
\text { Kanner } \\
24 \text { items rating } \\
\text { scale of Lotter } \\
\text { Kanner's criteria }\end{array}$ & $\begin{array}{l}4.1 \\
4.3 \\
0.7 \\
4.8\end{array}$ & $\begin{array}{l}2.7: 5.5 \\
2.4: 6.2 \\
0.6: 0.9 \\
2.1 ; 7.5\end{array}$ \\
\hline $\begin{array}{l}1983 \\
1984 \\
1986 \\
1987 \\
1987 \\
1988 \\
1988 \\
1989 \\
1989 \\
1989 \\
1991 \\
1992\end{array}$ & $\begin{array}{l}\text { Bohman et al. (44) } \\
\text { McCarthy et al. (45) } \\
\text { Steinhausen et al. (46) } \\
\text { Burd et al. (47) } \\
\text { Matsuishi et al. (48) } \\
\text { Tanoue et al. (49) } \\
\text { Bryson et al. (50) } \\
\text { Suqivama \& Abe (51) } \\
\text { Cialdella \& Mamelle (52) } \\
\text { Ritvo et al. (53) } \\
\text { Gillbera et al. (36) } \\
\text { Fombonne \& du }\end{array}$ & $\begin{array}{l}\text { Sweden } \\
\text { Ireland } \\
\text { Germany } \\
\text { USA } \\
\text { Japan } \\
\text { Japan } \\
\text { Canada } \\
\text { Japan } \\
\text { France } \\
\text { USA } \\
\text { Sweden } \\
\text { France }\end{array}$ & $\begin{array}{c}69.000 \\
65.000 \\
279.616 \\
180.986 \\
32.834 \\
95,394 \\
20.800 \\
12.263 \\
135.180 \\
769.620 \\
78.106 \\
274,816\end{array}$ & $\begin{array}{c}0-20 \\
10-\text { Auq } \\
0-14 \\
18-\mathrm{Feb} \\
12-\mathrm{Apr} \\
7 \\
\text { 14-Jun } \\
3 \\
\text { 9-Mar } \\
27-\mathrm{Mar} \\
\text { 13-Apr } \\
9 \& 13\end{array}$ & $\begin{array}{c}\text { Rutter criteria } \\
\text { Kanner } \\
\text { Rutter } \\
\text { DSM-III } \\
\text { DSM-III } \\
\text { DSM-III } \\
\text { New RDC } \\
\text { DSM-III } \\
\text { DSM-III like } \\
\text { DSM-III } \\
\text { DSM-III-R } \\
\text { Clinical-ICD-10 like }\end{array}$ & $\begin{array}{c}5.6 \\
4.3 \\
1.9 \\
3.26 \\
15.5 \\
13.8 \\
10.1 \\
13 \\
4.5 \\
2.47 \\
9.5 \\
4.9\end{array}$ & $\begin{array}{rl}3.9 & : 7.4 \\
2.7 & 5.9 \\
1.4 & 2.4 \\
2.4 & 4.1 \\
11.3: 19.8 \\
11.5: 16.2 \\
5.8: 14.4 \\
6.7: 19.4 \\
3.4: 5.6 \\
2.1: 2.8 \\
7.3: 11.6 \\
4.1: 5.7\end{array}$ \\
\hline $\begin{array}{l}1992 \\
1996 \\
1997 \\
1997 \\
1997\end{array}$ & $\begin{array}{l}\text { Mazaubrun (39) } \\
\text { Wianvosumarto et al. } \\
\text { Honda et al. (55) } \\
\text { Fombonne et al. (40) } \\
\text { Webb et al. (33) } \\
\text { Arvidsson et al. (56) }\end{array}$ & $\begin{array}{l}\text { Indonesia } \\
\text { Japan } \\
\text { France } \\
\text { UK } \\
\text { Sweden (West } \\
\text { Coast) }\end{array}$ & $\begin{array}{c}5.120 \\
8.537 \\
325.347 \\
73.301 \\
1,941\end{array}$ & $\begin{array}{l}\text { 7-Aor } \\
5 \\
\text { 16-Aug } \\
\text { 15-Mar } \\
6-\text { Mar }\end{array}$ & $\begin{array}{c}\text { CARS } \\
\text { ICD-10 } \\
\text { Clinical ICD-10-like } \\
\text { DSM-III-R } \\
\text { ICD-10 }\end{array}$ & $\begin{array}{c}11.7 \\
21.08 \\
5.35 \\
7.2 \\
46.4\end{array}$ & $\begin{aligned} 2.3 & : 21.1 \\
11.4 & : 30.8 \\
4.6 & : 6.1 \\
5.3 & : 9.3 \\
16.1 & ; 76.6\end{aligned}$ \\
\hline $\begin{array}{l}1998 \\
1999 \\
1999\end{array}$ & $\begin{array}{l}\text { Sponheim \& Skieldal (57) } \\
\text { Taylor et al. (22) } \\
\text { Kadesjo et al. (70) }\end{array}$ & $\begin{array}{l}\text { Norway } \\
\text { UK } \\
\text { Sweden } \\
\text { (Central) }\end{array}$ & $\begin{array}{c}65,688 \\
490,000 \\
826\end{array}$ & $\begin{array}{c}\text { 14-Mar } \\
0-16 \\
6.7-7.7\end{array}$ & $\begin{array}{c}\text { ICD-10 } \\
\text { ICD-10 } \\
\text { DSM-III-R/ICD-10 } \\
\text { Gillberg's criteria } \\
\text { (Asperger's) }\end{array}$ & $\begin{array}{c}5.2 \\
8.7 \\
72.6\end{array}$ & $\begin{aligned} 3.4 & : 6.9 \\
7.9 & : 9.5 \\
14.7 & : 130.6\end{aligned}$ \\
\hline $\begin{array}{l}2000 \\
2000\end{array}$ & $\begin{array}{l}\text { Baird et al. (58) } \\
\text { Powell et al. (59) }\end{array}$ & $\begin{array}{l}\text { UK } \\
\text { UK }\end{array}$ & $\begin{array}{l}16.235 \\
25,377\end{array}$ & $\stackrel{7}{7-J a n}$ & $\begin{array}{c}\text { ICD-10 } \\
\text { Clinica/ICD10/DS }\end{array}$ & $\begin{array}{c}30.8 \\
7.8\end{array}$ & $\begin{array}{l}22.9 ; 40.6 \\
5.8 ; 10.5\end{array}$ \\
\hline $\begin{array}{l}2000 \\
2001 \\
2001\end{array}$ & $\begin{array}{l}\text { Kielinen et al. (31) } \\
\text { Bertrand et al. (60) } \\
\text { Fombonne et al. (24) }\end{array}$ & $\begin{array}{l}\text { Finland } \\
\text { USA } \\
\text { UK }\end{array}$ & $\begin{array}{c}27.572 \\
8.896 \\
10,438\end{array}$ & $\begin{array}{l}\text { 7-May } \\
\text { 10-Mar } \\
\text { 15-May }\end{array}$ & $\begin{array}{c}\text { DSM-IV } \\
\text { DSM-IV } \\
\text { DSM-IVIICD-10 }\end{array}$ & $\begin{array}{l}20.7 \\
40.5 \\
26.1\end{array}$ & $\begin{array}{l}15.3: 26.0 \\
28.0: 56.0 \\
16.2: 36.0\end{array}$ \\
\hline $\begin{array}{l}2001 \\
2001\end{array}$ & $\begin{array}{l}\text { Magnússon and } \\
\text { Saemundsen (32) } \\
\text { Chakrabarti \& Fombonne }\end{array}$ & $\begin{array}{l}\text { Iceland } \\
\text { UK (Midlands) }\end{array}$ & $\begin{array}{l}43,153 \\
15,500\end{array}$ & $\begin{array}{l}\text { 14-May } \\
2.5-6.5\end{array}$ & $\begin{array}{l}\text { Mostly ICD-10 } \\
\text { ICD10/ }\end{array}$ & 16.8 & $\begin{array}{l}9.8 ; 16.6 \\
10.3 ; 23.2\end{array}$ \\
\hline $\begin{array}{l}2001 \\
2002\end{array}$ & $\begin{array}{l}\text { Davidovitch et al. (61) } \\
\text { Croen et al. (7) }\end{array}$ & $\begin{array}{l}\text { Israel } \\
\text { USA }\end{array}$ & $\begin{array}{c}26.160 \\
4,950,333\end{array}$ & $\begin{array}{l}\text { 11-Jul } \\
12-\text { May }\end{array}$ & $\begin{array}{l}\text { DSM-III-R/ } \\
\text { CDER \& Full }\end{array}$ & $\begin{array}{l}10 \\
11\end{array}$ & $\begin{array}{c}6.6: 14.4 \\
10.7 ; 11.3\end{array}$ \\
\hline $\begin{array}{l}2002 \\
2004 \\
2005\end{array}$ & $\begin{array}{l}\text { Madsen et al. (11) } \\
\text { Tebrueqae et al. (62) } \\
\text { Chakrabarti \& Fombonne }\end{array}$ & $\begin{array}{l}\text { Denmark } \\
\text { UK } \\
\text { UK (Midlands) }\end{array}$ & $\begin{array}{c}63,859 \\
2,536 \\
10,903\end{array}$ & $\begin{array}{c}8 \\
\text { 9-Aug } \\
\text { 7-Apr }\end{array}$ & $\begin{array}{l}\text { ICD-10 } \\
\text { ICD-10 } \\
\text { ICD-10/DSM-IV }\end{array}$ & $\begin{array}{c}7.2 \\
23.7 \\
22\end{array}$ & $\begin{array}{c}5.0-10.0 \\
9.6: 49.1 \\
14.4 ; 32.2\end{array}$ \\
\hline 2005 & Barbaresi et al (63) & USA, Minnesota & 37,726 & $0-21$ & DSM-IV & 29.7 & $24.0 ; 36.0$ \\
\hline $\begin{array}{l}2005 \\
2006\end{array}$ & $\begin{array}{l}\text { Honda et al (64) } \\
\text { Fombonne et al. (9) } \\
\text { Gillberg et al. (65) }\end{array}$ & $\begin{array}{l}\text { Japan } \\
\text { Canada } \\
\text { (Quebec) } \\
\text { Sweden }\end{array}$ & $\begin{array}{l}32,791 \\
27,749\end{array}$ & $\begin{array}{c}5 \\
17-\text { May }\end{array}$ & $\begin{array}{l}\text { ICD-10 } \\
\text { DSM-IV }\end{array}$ & $\begin{array}{l}37.5 \\
21.6\end{array}$ & $\begin{array}{l}31.0: 45.0 \\
16.5 ; 27.8 \\
29.2 ; 42.2\end{array}$ \\
\hline $\begin{array}{l}2006 \\
2007 \\
2007 \\
2007 \\
2008 \\
2009\end{array}$ & $\begin{array}{l}\text { Baird et al. (20) } \\
\text { Ellefsen et al. (66) } \\
\text { Oliveira et al. (67) } \\
\text { Latif and Williams (68) } \\
\text { Williams et al. (69) } \\
\text { Lazoff et al. (10) }\end{array}$ & $\begin{array}{l}\text { UK } \\
\text { Denmark } \\
\text { Portugal } \\
\text { UK } \\
\text { UK } \\
\text { Canada }\end{array}$ & $\begin{array}{c}56.946 \\
7,689 \\
67.795 \\
39.220 \\
14.062 \\
23.662\end{array}$ & $\begin{array}{c}\text { 10-Sep } \\
\text { 17-Aua } \\
9-\text { Jun } \\
0-17 \\
11 \\
5-17\end{array}$ & $\begin{array}{l}\text { ICD-10 } \\
\text { ICD-10 } \\
\text { DSM-IV } \\
\text { Kanner } \\
\text { ICD-10 } \\
\text { DSM-IV }\end{array}$ & $\begin{array}{c}38.9 \\
16 \\
16.7 \\
12.7 \\
21.6 \\
26.2\end{array}$ & $\begin{array}{c}29.9: 47.8 \\
7.0: 25.0 \\
14.0: 20.0 \\
9.0: 17.0 \\
13.9: 29.3 \\
19.7: 32.7\end{array}$ \\
\hline
\end{tabular}

Table 1: Prevalence surveys of autistic disorder

\section{PREVALENCE FOR COMBINED PDDS}

\section{Unspecified Autism Spectrum Disorders in Earlier Surveys}

Several studies performed in the 1960's and 1970's have provided useful information on rates of syndromes similar to autism but not meeting of the strict diagnostic criteria for autistic disorder then in use $(1,2)$. At the time, different labels were used by authors to characterize these clinical pictures, such as the triad of impairments involving deficits in reciprocal social interaction, communication, and imagination ( 16 ), and among others, autistic mental retardation (17). These syndromes would be falling within our currently defined autistic spectrum, probably with diagnostic labels such as atypical autism and/or pervasive developmental disorder - not otherwise specified (PDD-NOS). In 8 of 12 surveys providing separate estimates of the prevalence of these developmental disorders, higher rates for the atypical forms were found compared to those for more narrowly defined autistic disorder (see Fombonne, 2003, Table 3, p.172 (1)). This 
group received little attention in previous epidemiological studies and these subjects were not counted in the numerators of prevalence calculations, thereby underestimating systematically the prevalence of what would be defined today as the spectrum of autistic disorders. For example, in Wing et al.'s study (1976) (18), the prevalence was $4.9 / 10,000$ for autistic disorder, but, adding the figure of $16.3 / 10,000$ (16) corresponding to the triad of impairments, the prevalence for the whole PDD spectrum was in fact $21.1 / 10,000$. For historical purposes, it is important to be attentive to this earlier figure, bearing in mind that the study was conducted in the early 1970s and that autism occurring in subjects with an IQ within the normal range was not yet being investigated. Progressive recognition of the importance and relevance to autism of these less typical clinical presentations has led to changes in the design of more recent epidemiological surveys (see below), that are now using case definitions that incorporate upfront these milder phenotypes.

Newer Surveys of PDDs

The results of surveys that estimated the prevalence of the whole spectrum of PDDs are summarized in Table 2. Of the 23 studies listed, 13 also provided separate estimates for autistic disorder (see Table 1) and other types of PDD; 10 studies provided only an estimated rate for all the PDDs combined. Sample sizes ranged from 2,536 to 4,247,206 (median: 32,568; mean: $270,026)$ and the median age of samples ranged from 5.0 to 12.5 . The diagnostic criteria used in the studies listed in Table 2 reflect reliance on modern diagnostic schemes, such as the DSM-IV (19), the DSM-IV-TR (5) and the ICD-10 (6). In 14 studies where IQ data were reported, the proportion of subjects within the normal IQ range varied from $30 \%$ to $85.3 \%$ (median: $54.4 \%$; mean: $55.7 \%$ ), a proportion that is higher than that for autistic disorder and reflects the lesser degree of association, or lack thereof, between intellectual impairment and milder forms of PDD's. The male/female ratio ranged from 2.7 to 15.7 (mean: 5.5). There was a 6-fold variation in prevalence proportions among studies. The median rate was $61.9 / 10,000$ and the mean rate was $66.6 / 10,000$. This mean rate coincides with the rate reported recently for PDDs in 14 sites, in a large sample of 8-year-old US children born in 1994 (13). The CDC value represents, however, an

\begin{tabular}{|c|c|c|c|c|c|}
\hline References & Country & Size & Age & Prevalence/10,000 & $95 \% \mathrm{Cl}$ \\
\hline Baird et al, 2000 (58) & UK & 16,235 & 7 & 57.9 & $46.8-70.9$ \\
\hline Bertrand et al, $2001(60)$ & USA & 8,896 & 10-Mar & 67.4 & $51.5-86.7^{*}$ \\
\hline Chakrabarti \& Fombonne, 2001 (37) & UK & 15,500 & 7-Apr & 61.9 & $50.2-75.6$ \\
\hline Madsen et al, 2002 (11) & Denmark & - & 8 & 30 & - \\
\hline Scott et al, $2002(70)$ & UK & 33,598 & 11-May & $58.3^{\circ}$ & $50-67^{\circ}$ \\
\hline Yeargin-Allsopp et al, 2003 (72) & USA & 289,456 & 10-Mar & 34 & $32-36$ \\
\hline Gurney et al, 2003 (8) & USA & - & $8-10$ & $\begin{array}{c}52.0^{\dagger} \\
66\end{array}$ & - \\
\hline Icasiano et al, 2004 (73) & Australia & $\approx 54,000$ & $17-\mathrm{Feb}$ & 39.2 & -- \\
\hline Tebruegge et al., 2004 (62) & UK & 2,536 & 9-Aug & 82.8 & $51.3-126.3$ \\
\hline Chakrabarti \& Fombonne, 2005 (38) & UK & 10,903 & 6-Apr & 58.7 & $45.2-74.9$ \\
\hline Baird et al, $2006(20)$ & UK & 56,946 & 10-Sep & 116.1 & $90.4-141.8$ \\
\hline Fombonne et al, 2006 (9) & Canada & 27,749 & $5-17$ & 64.9 & $55.8-75.0$ \\
\hline Harrison et al, 2006 (34) & UK & 134,661 & $0-15$ & $44.2^{\ddagger}$ & $39.5-48.9$ \\
\hline Gillberg et al, 2006 (69) & Sweden & 32,568 & 712 & 80.4 & $71.3-90.3$ \\
\hline CDC, 2007a (12) & USA & 187,761 & 8 & 67 & $-\S$ \\
\hline CDC, 2007b (13) & USA & 407,578 & 8 & 66 & $63-68$ \\
\hline Ellefsen et al, 2007 (66) & Denmark & 7,689 & 17-Aug & 53.3 & $36-70$ \\
\hline Latif \& Williams, 2007 (68) & UK & 39,220 & $0-17$ & 61.2 & $54-69^{\circ}$ \\
\hline Wong et al, 2008 (74) & China & $4,247,206$ & $0-14$ & $\begin{array}{c}16.1(1986-2005) \\
30.0(2005)\end{array}$ & - \\
\hline Nicholas et al, 2008 (75) & USA & 47,726 & 8 & 62 & $56-70$ \\
\hline Kawamura et al, 2008 (21) & Japan & 12,589 & 8-May & 181.1 & $158.5-205.9^{*}$ \\
\hline Williams et al, 2008 (69) & UK & 14,062 & 11 & 61.9 & $48.8-74.9$ \\
\hline Lazoff et al, 2009 (9) & Canada & 23,662 & 17-May & 80.3 & $68.9-91.7$ \\
\hline
\end{tabular}

Table 2: Newer epidemiological surveys of PDDs 
average, and that study conducted at 14 different sites utilizing the same methodology found a three-fold variation of rate by state (13). Alabama had the lowest rate of 3.3/1,000 whereas New-Jersey had the highest value with 10.6/1,000 (13). As surveillance efforts continue, it is likely that awareness and services will develop in states that were lagging behind, resulting in a predictable increase in the average rate for the US as time elapses. These CDC findings apply to other countries as well, and prevalence estimates from any study should always be regarded in the context of the imperfect sensitivity in case ascertainment that results in downward biases in prevalence proportions.

In conclusion, the convergence of estimates around 60 to 70 per 10,000 for all PDDs combined, which translates into 1 child out of 150 suffering from a PDD, is striking especially when derived from studies with improved methodology. This is the best estimate for the prevalence of PDDs currently available; however, this represents an average figure and there is substantial variability across studies, and within studies, across sites or areas. However, some studies have reported rates that are even two to three times higher $(20,21)$.

\section{TIME TRENDS IN PREVALENCE AND THEIR INTERPRETATION}

The debate on the hypothesis of a secular increase in rates of autism has been obscured by a lack of clarity in the measures used by investigators to determine the occurrence of disease, or rather in their interpretation. Methodological requirements must be borne in mind whilst reviewing the evidence for a secular increase in rates of PDDs, or testing for the epidemic hypothesis. Several approaches to assess the question concerning a secular increase have been used in the literature that fall into 5 broad categories.

\section{a. Use of Inappropriate Referral Statistics}

Increasing numbers of children referred to specialist services or known to special education registers have been taken as evidence for an increased incidence of autismspectrum disorders. Upward trends in national registries, medical and educational databases have been seen in many different countries $(8,11,22,23)$. However, trends over time in referred samples are confounded by many factors such as referral patterns, availability of services, heightened public awareness, decreasing age at diagnosis and changes over time in diagnostic concepts and practices, to name only a few. Failure to control for these confounding factors was obvious in some recent reports (24), such as the widely quoted reports from California Developmental Database Services $(25,26)$. Firstly, these reports applied to numbers rather than rates, and failure to relate these numbers to meaningful denominators left the interpretation of an upward trend vulnerable to changes in the composition of the underlying population. Second, the focus on the year-to-year changes in absolute numbers of subjects known to California statefunded services detracts from more meaningful comparisons. Third, with one exception (see below), no attempt was made to adjust the trends for changes in diagnostic concepts and definitions. Fourth, age characteristics of the subjects recorded in official statistics were portrayed in a confusing manner where the preponderance of young subjects was presented as evidence of increasing rates in successive birth cohorts (24). Fifth, the decreasing age at diagnosis leads to increasing numbers of young children being identified in official statistics (27) or referred to already busy specialist services. Please see Fombonne, Quirke and Hagen (in press) (28) for a more elaborate analysis of these factors.

\section{b. The Role of Diagnostic Substitution}

One possible explanation for increased numbers of a diagnostic category is that children presenting with the same developmental disability may receive at one time one diagnosis, and later another diagnosis. Such substitution may occur when diagnostic categories are becoming increasingly known and recognized by health professionals and/or when access to better services is insured by using a new diagnostic category. The strongest evidence of "diagnostic switching" was produced in all US states in a complex analysis of Department of Education Data in 50 US states (23), indicating that a relatively high proportion of children previously diagnosed as having mental retardation were now identified as having a PDD diagnosis. Shattuck (2006) (23) showed that the odds of being classified in autism category increased by 1.21 during 1994-2003. In the meantime, the odds decreased significantly of being classified in the learning disability (LD) (odds ratio: $\mathrm{OR}=0.98)$ and the mental retardation (MR) categories $(\mathrm{OR}=0.97)$. However, this investigation has largely relied on ecological, aggregated data that have known limitations. Using individual level data, a new study has re-examined the hypothesis of diagnostic substitution in the California DDS dataset (29) and has shown that $24 \%$ of the increase in caseload was attributable to diagnostic substitution from mental retardation to autism. Similarly, a recent study in the UK (30) has shown that up to $66 \%$ of adults previously diagnosed as children with developmental language disorders would meet diagnostic criteria for a broad definition of PDD.

\section{c. Comparison of Cross-Sectional Epidemiological Surveys}

As shown earlier, epidemiological surveys of autism each possess unique design features which could 
account almost entirely for variations in rates among studies, and time trends in rates of autism are therefore difficult to gauge from published prevalence rates. The significant correlation previously mentioned between prevalence rate and year of publication for autistic disorder could merely reflect increased efficiency over time in case identification methods used in surveys as well as changes in diagnostic concepts and practices $(23,30,31,32,33)$. In studies using capture-recapture methods, a statistical method for indirectly estimating prevalence, it is apparent that up to a third of prevalent cases may be missed by an ascertainment source, even in recently conducted studies (34). Evidence that factors due to study methodology could account for most of the variability in published prevalence estimates comes from a direct comparison of 8 recent surveys conducted in the UK and the USA (2). In each country, 4 surveys were conducted around the same year and with similar age groups. As there is no reason to expect huge differences in rates across areas, prevalence estimates should therefore be comparable within each country. However, there was a six-fold variation in rates for UK surveys, and a fourteen-fold variation in US rates. In each set of studies, high rates derived from surveys where intensive population-based screening techniques were employed whereas lower rates were obtained from studies relying on passive administrative methods for case finding. Since no passage of time was involved, the magnitude of these gradients in rates can only be attributed to differences in case identification methods across surveys. Even more convincing evidence comes from the large survey by the CDC (13) where there was more than a three-fold variation in state specific rates (see above). However, the substantial differences reflected ascertainment variability across sites in a study that was otherwise performed with the same methods and at the same time. Thus, no inference on trends in the incidence of PDDs can be derived from a simple comparison of prevalence rates over time, since studies conducted at different periods are likely to differ even more with respect to their methodology.

\section{d. Repeat Surveys in Defined Geographical Areas}

Repeated surveys, using the same methodology and conducted in the same geographical area at different points in time, can potentially yield useful information on time trends provided that methods are kept relatively constant. The Göteborg studies $(35,36)$ provided three prevalence estimates which increased over a short period of time from 4.0 (1980) to 6.6 (1984) and 9.5/10,000 (1988) (36). However, comparison of these rates is not straightforward as different age groups were included in each survey. Secondly, the increased prevalence in the second survey was explained by improved detection among the mentally retarded, and that of the third survey by cases born to immigrant parents. That the majority of the latter group was born abroad suggests that differential migration into the area could be a key explanation. Taken in conjunction with a change in local services and a progressive broadening of the definition of autism over time acknowledged by the authors (36), these findings do not provide evidence for an increased incidence in the rate of autism. Two separate surveys of children born 1992-1995 and 19961998 in Staffordshire in the UK $(37,38)$ were performed with rigorously identical methods for case definition and case identification. The prevalence for combined PDDs was comparable and not statistically different in the 2 surveys (38), suggesting no upward trend in overall rates of PDDs, at least during the short time interval between studies.

\section{e. Successive Birth Cohorts}

In large surveys encompassing a wide age range, increasing prevalence rates among most recent birth cohorts could be interpreted as indicating a secular increase in the incidence of the disorder, provided that alternative explanations can confidently be eliminated. This approach was used in two large French surveys $(39,40)$. The surveys included birth cohorts from 1972 to 1985 (735,000 children, 389 of whom had autism), and, pooling the data of both surveys, age-specific rates showed no upward trend (40). An additional example is provided in the analysis of Gurney and colleagues' (2003) (8) study in which a sixteen-fold increase in the number of children identified with a PDD from 19911992 to 2001-2002 was shown to not be specific to autism since, during the same period, an increase of $50 \%$ was observed for all disability categories identified. In addition, the analysis also showed a marked period effect that identified the early 1990s as the period where rates started to increase in all ages and birth cohorts.

\section{CONCLUSION}

The recent upward trend in rates of prevalence cannot be directly attributed to an increase in the incidence of the disorder, or to an 'epidemic' of autism. There is good evidence that changes in diagnostic criteria, diagnostic substitution, changes in the policies for special education, and the increasing availability of services are responsible for the higher prevalence figures. The rise in number of children diagnosed occurred at the same time in many countries, when radical shifts occurred in the ideas, diagnostic approaches and services for children with PDDs. Alternatively, this might, of course, reflect the effect of environmental influences operating simultaneously in 
different parts of the world. However, there has been no proposed and legitimate risk mechanism to account for this world-wide effect. Most of the existing epidemiological data are inadequate to properly test hypotheses on changes in the incidence of autism in human populations. Moreover, due to the relatively low frequency of autism and PDDs, variations of small magnitude in the incidence of the disorder are very likely to go undetected. Equally, the possibility that a true increase in the incidence of PDDs has also partially contributed to the upward trend in prevalence rates cannot, and should not, be eliminated based on available data.

From recent studies, a best estimate of 60 to $70 / 10,000$ (equivalences $=6$ to $7 / 1,000$; or 0.6 to $0.7 \%$; or 1 child in about 150 children) can be confidently derived for the prevalence of autism spectrum disorders. Current evidence does not strongly support the hypothesis of a secular increase in the incidence of autism, but statistical power to detect time trends is seriously limited in existing datasets. To assess whether or not the incidence has increased, method factors which account for an important proportion of the variability in rates must be tightly controlled. New survey methods have been developed to be used in multinational comparisons, and ongoing surveillance programs will inform soon this hypothesis. Meanwhile, the available prevalence figures carry straightforward implications for current and future needs in services and early educational intervention programs.

\section{REFERENCES}

1. Fombonne, E. (2003). Epidemiological surveys of autism and other pervasive developmental disorders: An update. J Autism Dev Disord, 33(4), 365-382.

2. Fombonne, E. (2005). Epidemiology of autistic disorder and other pervasive developmental disorders. J Clin Psychiatry, 66 Suppl 10, 3-8.

3. Williams, J. G., Higgins, J. P., \& Brayne, C. E. (2006). Systematic review of prevalence studies of autism spectrum disorders. Arch Dis Child, 91(1), 8-15.

4. Fombonne E. (2007) Epidemiology. In : Lewis's Child and Adolescent Psychiatry : A Comprehensive Textbook, 4th Edition. Eds. A Martin \& F Volkmar. Lippincott, Williams and Wilkins Publishing, pp. 150-171.

5. American Psychiatric Association (2000) Diagnostic and Statistical Manual of Mental Disorders - TR. 4th Edition. Washington, DC.

6. The ICD-10 Classification of Mental and Behavioural Disorders. Clinical descriptions and diagnostic guidelines. Geneva, World Health Organization, 1992.

7. Croen, L. A., Grether, J. K., Hoogstrate, J., \& Selvin, S. (2002). The changing prevalence of autism in California. Journal of Autism and Developmental Disorders, 32(3), 207- 215.

8. Gurney, J. G., Fritz, M. S., Ness, K. K., Sievers, P., Newschaffer, C. J., \& Shapiro, E. G. (2003). Analysis of prevalence trends of autism spectrum disorder in Minnesota.[comment]. Archives of Pediatrics \& Adolescent Medicine., 157(7), 622-627.

9. Fombonne, E., Zakarian, R., Bennett, A., Meng, L., \& McLean-
Heywood, D. (2006). Pervasive developmental disorders in Montreal, Quebec, Canada: Prevalence and links with immunizations. Pediatrics, 118(1), e139-150.

10. Lazoff, T., Piperni, T., Clarke E., Lewis, L. \& Fombonne, E. (2009) Prevalence rates of PDD among children at the English Montreal School Board. Presented at the 8th Annual International Meeting for Autism Research (IMFAR), Chicago, Illinois, USA, May 7-9, 2009.

11. Madsen, K. M., Hviid, A., Vestergaard, M., Schendel, D., Wohlfahrt, J., Thorsen, P., et al. (2002). A population-based study of measles, mumps, and rubella vaccination and autism. N Engl J Med, 347(19), 1477-1482.

12. Center for Disease Control: Prevalence of autism spectrum disorders--autism and developmental disabilities monitoring network, six sites, United States, 2000. MMWR Surveill Summ 2007a; 56(1):1-11

13. Center for Disease Control: Prevalence of autism spectrum disorders--autism and developmental disabilities monitoring network, 14 sites, United States, 2002. MMWR Surveill Summ 2007b; 56(1):12-28

14. LeCouteur, A., Rutter, M., Lord, C., Rios, P., Robertson, S., Holdgrafer, M., et al. (1989). Autism diagnostic interview: A standardized investigator-based instrument. Journal ofAutism and Developmental Disorders, 19, 363-387.

15. Lord, C., Risi, S., Lambrecht, L., Cook, E. H., Jr., Leventhal, B. L., DiLavore, P. C., et al. (2000). The autism diagnostic observation schedule-generic: A standard measure of social and communication deficits associated with the spectrum of autism. J Autism Dev Disord, 30(3), 205-223.

16. Wing, L., \& Gould, J. (1979). Severe impairments of social interaction and associated abnormalities in children: Epidemiology and classification. Journal of Autism and Developmental Disorders, 9, 11-29.

17. Hoshino, Y., Kumashiro, H., Yashima, Y., Tachibana, R., \& Watanabe, M. (1982). The epidemiological study of autism in Fukushima Ken. Folia Psychiatrica et Neurologica Japonica, 36, 115-124.

18. Wing, L., Yeates, S., Brierly, L., \& Gould, J. (1976). The prevalence of early childhood autism: Comparison of administrative and epidemiological studies. Psychological Medicine, 6, 89-100. 14

19. American Psychiatric Association (1994) Diagnostic and Statistical Manual of Mental Disorders. 4th Edition. Washington, DC.

20. Baird, G., Simonoff, E., Pickles, A., Chandler, S., Loucas, T., Meldrum, D., et al. (2006). Prevalence of disorders of the autism spectrum in a population cohort of children in South Thames: The special needs and autism project (SNAP). Lancet, 368(9531), 210-215.

21. Kawamura, Y., Takahashi, O., \& Ishii, T. (2008). Reevaluating the incidence of pervasive developmental disorders: Impact of elevated rates of detection through implementation of an integrated system of screening in Toyota, Japan. Psychiatry Clin Neurosci, 62(2), 152-159.

22. Taylor, B., Miller, E., Farrington, C., Petropoulos, M.-C., FavotMayaud, I., Li, J., et al. (1999). Autism and measles, mumps, and rubella vaccine: No epidemiological evidence for a causal association. The Lancet, 353(June 12), 2026-2029.

23. Shattuck, P. T. (2006). The contribution of diagnostic substitution to the growing administrative prevalence of autism in US special education. Pediatrics, 117(4), 1028- 1037.

24. Fombonne, E., Simmons, H., Ford, T., Meltzer, H., \& Goodman, R. (2001). Prevalence of pervasive developmental disorders in the British nationwide survey of child mental health. Journal of the American Academy of Child \& Adolescent Psychiatry., 40(7), 820-827. 
25. California Department of Developmental Services. Changes in the population of persons with autism and pervasive developmental disorders in California's Developmental Services System: 1987 through 1998. Report to the Legislature March 1, 199919 pages. http://www.dds.ca.gov

26. California Department of Developmental Services. Autism Spectrum Disorders: Changes in the California caseload - an update 1999 through 2002. April 2003 (http://www.dds.ca.gov/Autism/pdf/AutismReport2003.pdf)

27. Wazana, A., Bresnahan, M., \& Kline, J. (2007). The autism epidemic: Fact or artifact? J Am Acad Child Adolesc Psychiatry, 46(6), 721-730.

28. Fombonne E, Quirke S, Hagen A. Epidemiology of pervasive developmental disorders. In: Autism Spectrum Disorders. Amaral DG, Dawson G, and Geschwind DH (Eds). Oxford University Press. 2009, In Press.

29. King, M., \& Bearman, P. (in press) Diagnostic change and the increase in prevalence of autism. International Journal of Epidemiology.

30. Bishop, D. V., Whitehouse, A. J., Watt, H. J., \& Line, E. A. (2008). Autism and diagnostic substitution: Evidence from a study of adults with a history of developmental language disorder. Dev Med Child Neurol, 50(5), 341-345.

31. Kielinen, M., Linna, S.-L., \& Moilanen, I. (2000). Autism in northern Finland. European Child and Adolescent Psychiatry, 9, 162-167.

32. Magnusson, P., \& Saemundsen, E. (2001). Prevalence of autism in Iceland. J Autism Dev Disord, 31(2), 153-163.

33. Webb, E., Lobo, S., Hervas, A., Scourfield, J., \& Fraser, W. (1997). The changing prevalence of autistic disorder in a Welsh health district. Developmental Medicine and Child Neurology, $39,150-152$.

34. Harrison, M. J., O'Hare, A. E., Campbell, H., Adamson, A., \& McNeillage, J. (2006). Prevalence of autistic spectrum disorders in Lothian, Scotland: An estimate using the "capture-recapture" technique. Arch Dis Child, 91(1), 16-19.

35. Gillberg, C. (1984). Infantile autism and other childhood psychoses in a Swedish urban region. Epidemiological aspects. J Child Psychol Psychiatry, 25(1), 35-43.

36. Gillberg, C., Steffenburg, S., \& Schaumann, H. (1991). Is autism more common now than ten years ago? British Journal of Psychiatry, 158, 403-409.

37. Chakrabarti, S., \& Fombonne, E. (2001). Pervasive developmental disorders in preschool children. Journal of the American Medical Association (JAMA), 285(24), 3093-3099.

38. Chakrabarti, S., \& Fombonne, E. (2005). Pervasive developmental disorders in preschool children: Confirmation of high prevalence. Am J Psychiatry, 162(6), 1133-1141.

39. Fombonne, E., \& du Mazaubrun, C. (1992). Prevalence of infantile autism in four French regions. Social Psychiatry \& Psychiatric Epidemiology, 27(4), 203-210.

40. Fombonne, E., Du Mazaubrun, C., Cans, C., \& Grandjean, H. (1997). Autism and associated medical disorders in a French epidemiological survey. Journal of the American Academy of Child \& Adolescent Psychiatry., 36(11), 1561-1569.

41. Lotter, V. (1966). Epidemiology of autistic conditions in young children: I. Prevalence. Social Psychiatry, 1, 124-137.

42. Brask, B. (1972). A prevalence investigation of childhood psychoses. Paper presented at the Nordic Symposium on the Care of Psychotic Children, Oslo.

43. Treffert, D. A. (1970). Epidemiology of infantile autism. Archives of General Psychiatry, 22, 431-438.

44. Bohman, M., Bohman, I., Bjorck, P., \& Sjoholm, E. (1983). Childhood psychosis in a northern Swedish county: Some preliminary findings from an epidemiological survey. In M.
Schmidt \& H. Remschmidt (Eds.), Epidemiological approaches in child psychiatry (pp. 164-173). Stuttgart: Georg Thieme Verlag.

45. McCarthy, P., Fitzgerald, M., \& Smith, M. (1984). Prevalence of childhood autism in Ireland. Irish Medical Journal, 77, 129-130.

46. Steinhausen, H.-C., Gobel, D., Breinlinger, M., \& Wohlloben, B. (1986). A community survey of infantile autism. Journal of the American Academy of Child Psychiatry, 25, 186-189.

47. Burd, L., Fisher, W., \& Kerbeshan, J. (1987). A prevalance study of pervasive developmental disorders in North Dakota. Journal of the American Academy of Child and Adolescent Psychiatry, 26, 700-703.

48. Matsuishi, T., Shiotsuki, M., Yoshimura, K., Shoji, H., Imuta, F., \& Yamashita, F. (1987). High prevalence of infantile autism in Kurume city, Japan. Journal of Child Neurology, 2, 268-271.

49. Tanoue, Y., Oda, S., Asano, F., \& Kawashima, K. (1988). Epidemiology of infantile autism in southern Ibaraki, Japan: Differences in prevalence in birth cohorts. Journal of Autism and Developmental Disorders, 18, 155-166.

50. Bryson, S. E., Clark, B. S., \& Smith, I. M. (1988). First report of a Canadian epidemiological study of autistic syndromes. Journal of Child Psychology \& Psychiatry \& Allied Disciplines, 29(4), 433-445.

51. Sugiyama, T., \& Abe, T. (1989). The prevalence of autism in Nagoya, Japan: A total population study. Journal of Autism and Developmental Disorders, 19, 87-96.

52. Cialdella, P., \& Mamelle, N. (1989). An epidemiological study of infantile autism in a French department (Rhone): A research note. Journal of Child Psychology \& Psychiatry \& Allied Disciplines, 30(1), 165-175.

53. Ritvo, E., Freeman, B., Pingree, C., Mason-Brothers, A., Jorde, L., Jenson, W., et al. (1989). The UCLA-University of Utah epidemiologic survey of autism: Prevalence. American Journal of Psychiatry, 146, 194-199.

54. Wignyosumarto, S., Mukhlas, M., \& Shirataki, S. (1992). Epidemiological and clinical study of autistic children in Yogyakarta, Indonesia. Kobe Journal of Medical Sciences, 38(1), 1-19.

55. Honda, H., Shimizu, Y., Misumi, K., Niimi, M., \& Ohashi, Y. (1996). Cumulative incidence and prevalence of childhood autism in children in Japan. British Journal of Psychiatry, 169, 228-235.

56. Arvidsson, T., Danielsson, B., Forsberg, P., Gillberg, C., Johansson, M., \& Kjellgren, G. (1997). Autism in 3-6 year-old in a suburb of Goteborg, Sweden. Autism, 2, 163-173.

57. Sponheim, E., \& Skjeldal, O. (1998). Autism and related disorders: Epidemiological findings in a Norwegian study using icd-10 diagnostic criteria. Journal of Autism and Developmental Disorders, 28, 217-227.

58. Baird, G., Charman, T., Baron-Cohen, S., Cox, A., Swettenham, J., Wheelwright, S., et al. (2000). A screening instrument for autism at 18 months of age: A 6 year follow-up study. Journal of the American Academy of Child and Adolescent Psychiatry, 39, 694-702.

59. Powell, J., Edwards, A., Edwards, M., Pandit, B., SungumPaliwal, S., \& Whitehouse, W. (2000). Changes in the incidence of childhood autism and other autistic spectrum disorders in preschool children from two areas of the West Midlands, UK. Developmental Medicine and Child Neurology, 42, 624-628.

60. Bertrand, J., Mars, A., Boyle, C., Bove, F., Yeargin-Allsopp, M., \& Decoufle, P. (2001). Prevalence of autism in a United States population: The Brick Township, New Jersey, investigation. Pediatrics., 108(5), 1155-1161.

61. Davidovitch, M., Holtzman, G., \& Tirosh, E. (2001). Autism in the Haifa area - an epidemiological perspective. Israeli Medical Association Journal, 3(March), 188-189. 
62. Tebruegge, M., Nandini, V., \& Ritchie, J. (2004). Does routine child health surveillance contribute to the early detection of children with pervasive developmental disorders? An epidemiological study in Kent, UK. BMC Pediatr, 4, 4.

63. Barbaresi, W. J., Katusic, S. K., Colligan, R. C., Weaver, A. L., \& Jacobsen, S. J. (2005). The incidence of autism in Olmsted County, Minnesota, 1976-1997: results from a population-based study. Arch Pediatr Adolesc Med, 159(1), 37-44.California Department of Developmental Services, December 2007, Table 4 http://www.dds.ca.gov/FactsStats/docs/Dec07_QRTTBLS.pdf (verified January 28th, 2009)

64. Honda, H., Shimizu, Y., \& Rutter, M. (2005). No effect of MMR withdrawal on the incidence of autism: A total population study. J Child Psychol Psychiatry, 46(6), 572-579.

65. Gillberg, C., Cederlund, M., Lamberg, K., \& Zeijlon, L. (2006). Brief report: "the autism epidemic". The registered prevalence of autism in a Swedish urban area. J Autism Dev Disord, 36(3), 429-435.

66. Ellefsen, A., Kampmann, H., Billstedt, E., Gillberg, I. C., \& Gillberg, C. (2007). Autism in the Faroe islands: An epidemiological study. J Autism Dev Disord, 37(3), 437-444.

67. Oliveira, G., Ataide, A., Marques, C., Miguel, T. S., Coutinho, A. M., Mota-Vieira, L., et al. (2007). Epidemiology of autism spectrum disorder in Portugal: Prevalence, clinical characterization, and medical conditions. Dev Med Child Neurol, 49(10), 726-733.
68. Latif, A. H., \& Williams, W. R. (2007). Diagnostic trends in autistic spectrum disordersin the South Wales valleys. Autism, 11(6), 479-487.

69. Williams, E., Thomas, K., Sidebotham, H., \& Emond, A. (2008). Prevalence and characteristics of autistic spectrum disorders in the ALSPAC cohort. Dev Med Child Neurol, 50(9), 672-677.

70. Kadesjo, B., Gillberg, C., \& Hagberg, B. (1999). Brief report: Autism and Asperger syndrome in seven-year-old children: A total population study. J Autism Dev Disord, 29(4), 327-331.

71. Scott, F. J., Baron-Cohen, S., Bolton, P., \& Brayne, C. (2002). Brief report: Prevalence of autism spectrum conditions in children aged 5-11 years in Cambridgeshire, UK. Autism, 6(3), 231-237.

72. Yeargin-Allsopp, M., Rice, C., Karapurkar, T., Doernberg, N., Boyle, C., \& Murphy, C. (2003). Prevalence of autism in a us metropolitan area.[comment]. JAMA, 289(1), 49-55.

73. Icasiano, F., Hewson, P., Machet, P., Cooper, C., \& Marshall, A. (2004). Childhood autism spectrum disorder in the Barwon region: A community based study. J Paediatr Child Health, 40(12), 696-701.

74. Wong, V. C., \& Hui, S. L. (2008). Epidemiological study of autism spectrum disorder in China. J Child Neurol, 23(1), 67-72.

75. Nicholas, J. S., Charles, J. M., Carpenter, L. A., King, L. B., Jenner, W., \& Spratt, E. G. (2008). Prevalence and characteristics of children with autism-spectrum disorders. Ann Epidemiol, 18(2), 130-136.

Dr Eric Fombonne is Professor of Psychiatry at McGill University and Canada Research Chair in Child Psychiatry. From 2001 to 2009, he was Head of the Division of Child Psychiatry at McGill University, and Director of the Department of Psychiatry at the Montreal Children's Hospital. Since he arrived in Montreal, he has consolidated the Autism Spectrum Disorder program and is now heading a research program that looks at environmental risk factors, at immunological factors and at genes in autism. Since 2003, he has been running a large training grant to autism research funded by CIHR, FRSQ and NAAR. He established a special lectureship fund (the Donald Cohen Lectureship Childhood Autism Lectureship) to support a yearly lecture and research event on autism with international experts.

Sara Quirke is an M.A. student in McGill University's School and Applied Child Psychology program. Her thesis focuses on parents' positive perceptions in caring for a child with an autism spectrum disorder, and her supervisors are Eric Fombonne, M.D. and Tara Flanagan, Ph.D. She has recently been accepted as a student in the Autism Research Training Program based at McGill and McMaster University, and she is part of the research team at the Montreal Children's Hospital's Autism Spectrum Disorder clinic. She aspires to work as a clinician and researcher in child psychology.

Dr Hagen is an Associate Professor at McGill University in the Division of Child and Adolescent psychiatry within the Department of Psychiatry. She trained in medicine and as a child psychiatry specialist at the Mayo Clinic, Rochester, Minnesota. She has interests in the evaluation and management of complex neuropsychiatric disorders. At the Montreal Children's Hospital, she is one of the team of physicians operating in the different services of the Autism Spectrum Disorder clinical program. 